Hagen. A recent report to Sir Walter McNicoll, administrator of the Mandated Territory, by Mr. J. L. Taylor, assistant district officer, records the results of a patrol carried out by him in unexplored country westward from Mt. Hagen to the border of Dutch New Guinea, and northward towards the southern tributaries of the Sepik River during March 9, 1938-June 19, 1939. 'The area surveyed consisted of some 20,000 square miles, and was found to be for the most part of temperate climate, such as might be suitable for European oceupation. The future of the country traversed is said to lie in agriculture and pig-raising.

Large numbers of natives were encountered, most of whom appear to have been friendly, though on more than one occasion the patrol was attacked and suffered some casualties. Among natives to the north-west of Mt. Hagen, who had not previously seen a white man, the members of the patrol were regarded as spirits of the dead returned to earth. One of them, while taking observations from a tree, received the offering of a pig and was asked to ascend to heaven. In another village, the women were kept at a distance in the belief that they would die if they beheld these spirits. Among the more remarkable features in the culture of the peoples encountered, of which some particulars are given in a dispatch from the Canberra correspondent of The Times in. the issue of March 26, is a system of deep drains or sunken roads, in the form of an elaborate complex of trenches, which serves both for defence and in cultivation as an effective drainage system, or as a protection against the ravages of pigs. Another romarkable culture trait is the use of wigs of human hair, made by professional wig-makers. Each man, it is said, aimed at having at least one wig made of his own hair. The tribes of the area were found to be keen traders, the most important and much sought after commodity being salt prepared frcm wood burnt after saturation in salt-springs.

\section{Archæological Investigations in Jerusalem}

Excavation of the remains of certain of the ancient walls of Jerusalem carried out by Mr. C. N. Johns on behalf of the Department of Antiquities has produced results of considerable archæological interest and historical importance. These results include the establishment of a chronological sequence in the remains of these ancient walls, which carries back to pre-Herodian times-certainly to the Maccabees and possibly even to the days of Nehemiah, although the evidence for the latter is archæologically undated. A further result is the confirmation of a tentative identification, made in the seventies of the last century, of the so-called Tower of David with Phasael, the third of the three towers described by Josephus as erected by Herod the Great. The systematic exploration of the site was made possible by the demolition of the Turkish barracks under the British occupation, and was undertaken by the Department of Antiquities in 1934 through the direct personal interest of Sir Arthur Wauchope, then High Commissioner.
The excavation, as described in a dispatch from the Jerusalem correspondent of The Times in the issue of March 23, has laid bare the old wall inside and parallel to the present north and west walls of the Citadel as reconstructed by the Crusaders and Mamelukes. This fragment of the old wall consists of three towers, Phasael and those named respectively by the excavators the Corner Tower and the South Tower, and their connecting curtain walls. The curtain between Phasael and the Corner Tower is of erude chalky stone solidly laid without mortar on the native rock scarp. Stratified remains of pottery suggest that this may go back to Jonathan Maccabæus; but in fact it incorporates an even earlier and clumsier wall, as previously mentioned, archæologically undated. The Maccabæan wall was partially demolished shortly after its erection, in a battle, presumably during the sieges by one or other of the Antiochus dynasty, of which the relics are seen in iron and bronze javelin heads and stone ballista balls. There is now evidence that after repairs it was reconstructed in the remarkable protective works of Herod, in which the tower Phasael was the strongest and most striking, rising from a cube of solid masonry, measuring $68 \mathrm{ft}$. on each side, in two stages to a height of $155 \mathrm{ft}$. In addition to their intrinsic interest, these discoveries will tend to throw light on other problems of the character and appearance of the Holy City at the opening of our era.

\section{Trotula and the Ladies of Salerno}

Is a paper read before the Section of the History of Medicine of the Royal Society of Medicine on January 10, Dr. H. P. Bayon stated that several contemporary writers maintained that a fictitious Trottus was the author of "De passionibus mulierum", which was usually ascribed to Trotula of Salerno, a matron mentioned in the text of most manuscript copies and therefore a definite person. Whether she wrote or compiled the chapters "De ornatu mulierum" is not ascertained, but a study of early manuscript texts dealing with cosmetics seems to afford some clue. The gynæcological chapters are notable because of the recommendation of the support of the perinæum in childbirth and the primary suture of the perinæum. The many manuscript copies, printings and literary allusions concur in showing the appreciation which Trotula enjoyed during the twelfth to sixteenth centuries.

The references in the text of Trotula's work to Saracens, many drugs from the East, the avoidance of magical formulæ and hagiology, together with the description of alchemical manipulations, indicate the personal influence of Moslem and Hebrew physicians ; in other Salernitan writings, quotations from the Old Testament are preferred. It is recorded that Costanza of Salerno lectured on medicine during the reign of Giovanna I of Anjou (1326-82); she was probably the first woman professor. The decline of the College of Salerno must have occurred after its destruction in the sack of the town in 1194. In academical teaching Salernitan doctrines were replaced by dialectic scholastic medicine, but the 
College of Salerno brought to the West a system of professional medical practice which has since prevailed in all parts of the civilized world.

\section{A New Kind of Museum Exhibit}

THE New England Museum of Natural History in Boston, Mass., has been the first to turn a trade innovation in lighting to the service of museum galleries. In the particular case described by Bradford Washburn in the Museums Journal $(39,450 ; 1940)$ you gaze at a stoat watching you from the edge of a summer wood. As you look, the lights fade, become momentarily dim, and when the full light shows again the summer scene has gone, snow covers the ground, the trees are bare of leaves, and the stoats have changed into their winter dress of ermine. The case really contains two groups, a summer and a winter one ; but the spectator looking at the summer group perceives it, when it is brilliantly lit internally, through a transparent sheet of Belgian 'black' glass. When the internal lights fade and the second group is illuminated, the black glass becomes opaque and acts as a mirror in which only the snow scene is visible, exactly overlapping the summer scene, of which it is a replica in reverse. Many technical difficulties had to be surmounted before the new exhibit was satisfactorily completed ; but its dissolving habitat group at once made a great impression. One wonders if the average mortal really needs such bait in order to be induced to look at a representation of Nature: and the result--half his mind is thinking about the trick of the thing; only the other half is giving itself to the study of the Nature group.

\section{Earthquakes Near Great Dams}

According to Earthquake Notes (11, No. 3; January 1940), earthquakes of varying intensity have been recorded from the neighbourhood of Boulder Dam since September 1936. During the first four months twelve shocks were felt, but the frequency increased until during A.pril 1937 forty-five were felt. After this time the frequency increased until during the early part of 1939 there were on average two humanly felt earthquakes a month. The Wood-Anderson seismograph on the spot recorded more than five hundred disturbances during 1938. There has been some discussion among U.S. seismologists of plans for the observation of possible earthquakes in the neighbourhood of two other areas which will probably be similarly loaded. The first is the unfinished Grand Coulee Dam in the State of Washington, and the second is the proposed Shasta Dam near the confluence of the Pit and Sacramento Rivers in northern California. In the latter case there is yet time to obtain information of the seismicity of the area before loading. Similar data were not obtained in the case of the Boulder Dam.

\section{Oxygen Administration and Inhalation Apparatus}

A FIFTH memorandum in the Emergency Medical Services Series has been issued by the Ministry of Health entitled "Oxygen Administration-Indica- tions, Methods and Types of Apparatus" (H.M. Stationery Office. 2d. net). The administration of oxygen is a valuable aid in the treatment of some forms of gas poisoning and lung disease, and in some surgical conditions such as shock and chest wounds. The memorandum incorporates the results of research on the subject, and is intended primarily for the guidance of medical officers in charge of hospitals. It describes the conditions for which oxygen therapy is likely to be effective, methods of oxygen administration, and the more important types of apparatus for the purpose, including a new form of nasal mask.

\section{Alexander Pedler Lecture}

The Alexander Pedler Lecture, which is given annually under the auspices of the British Association, was this year delivered by Prof. Allan Ferguson before the Cardiff Naturalists' Society. The lecture, which was given in the Reardon Smith Lecture Theatre of the National Museum of Wales, Cardiff, on March 14, was entitled "Splashes, and what they Teach". It was chiefly concerned with an explanation of the phenomena attendant on the impact of a drop of liquid on a liquid or solid surface. A high-speed film was shown which illustrated the phenomena, and the results were compared with those of the earlier classical experiments carried out by the late Prof. Worthington.

\section{Old Books on Social Sciences}

WE have received a copy of Catalogue 54 published by E. P. Goldschmidt and Co., of 45 Old Bond Street, W.1, containing 307 items of old works dealing with a great variety of subjects. Attention may be directed to the following: Jacques Legrand's "Sophologium", a popular handbook of useful knowledge, possibly printed by Caxton, not later than 1473; Naudé's work on the principles of librarianship and library organization (1627); Beccaria's treatise on crimes and penalties (1766); Sir Edwin Chadwick's "Report on the Sanitary Condition of the Labouring Population of Great Britain" (1842) ; Patissier's work on factory hygiene and the diseases to which miners, industrial workers and others are exposed (1822); Schreiber's sixteenth century book on practical arithmetic, the first German book on the subject; Jérome de Monteux's treatise on hygiene, which contains chapters on dietetics, the care and nourishment of children, and a section on cosmetics (1559); Bernard Palissy's discourse on the nature of waters, fountains, rains, metals, salts, stones, earths and fire (1580), which entitles him to be regarded as one of the pioneers of modern chemistry and geology; Neander's "Tabacologia" (1626), the most important early work on tobacco ; Villafranca's "Methodus refrigerandi" (1550), the earliest work on artificial refrigeration; and the first edition of Linnæus's book on the increase of the habitable earth (1744) bound up with the second edition of his oration on travelling in one's own country (1743). 